\title{
Beden Eğitimi Öğretmen Adaylarının Bilişötesi Öğrenme Stratejileri, Akademik Öz-Yeterlikleri ve Öğretmenlik Mesleğine Yönelik Tutumları
}

\section{Metacognitive Learning Strategies and Academic Self-Efficacy of Pre-Service Physical Education Teachers and Their Attitudes Towards The Profession of Teaching}

\author{
Araştırma Makalesi
}

Sonnur KÜÇÜK KILIÇ, Hamit CIHAN, Erman ÖNCÜ

Karadeniz Teknik Üniversitesi, Beden Eğitimi ve Spor Yüksekokulu

\section{öz}

u araştırmanın amacl; beden eğitimi öğretmen adaylarının bilişötesi öğrenme stratejilerini, akademik öz-yeterlik algılarını ve öğretmenlik mesleğine yönelik tutumlarını bazı değişkenlere göre incelemek ve aralarındaki ilişkiyi belirlemektir. Araştırmanın çalışma grubunu 610 beden eğitimi öğretmen adayı oluşturmuştur. Araştırmada veri toplama aracı olarak 'Bilişötesi Öğrenme Stratejileri Ölçeği (BÖSÖ)', 'Akademik Öz-Yeterlik Ölçeği (AÖYÖ)' ve ‘Öğretmenliğe IIlişkin Tutum Ölçeği (ÖiTÖ)' kullanılmıştır. Veriler, betimsel istatistik yöntemler, t-testi, MANOVA, ANOVA ve Pearson Correlation testleri kullanılarak analiz edilmiştir. Araştırmadan elde edilen bulgular doğrultusunda, çalışma grubunda yer alan katılımcıların akademik öz-yeterlikleri ile

\section{A B S TR ACT}

The purpose of this study was to analyze metacognitive learning strategies and academic selfefficacy perceptions of pre-service physical education $(P E)$ teachers and their attitudes towards the profession of teaching according to some demographic variables, and to determine the relationship between these variables. This study was conducted on 610 pre-service PE teachers. The Metacognitive Learning Strategies Scale (MLSS), the Academic Self-Efficacy Scale (ASES) and the Teaching Profession Attitude Scale (TPAS) were administered on the participants. Descriptive statistical methods, t test, MANOVA, ANOVA and correlation analysis were used in the data analysis. Whereas significant difference was not found in the values of academic self-efficacy 
öğretmenlik mesleğine yönelik tutumları cinsiyet değişkenine göre anlamlı bir şekilde farklılaşmazken, bilişötesi öğrenme stratejileri cinsiyet değişkenine göre sadece 'Planlama', 'Örgütleme', ve 'Denetleme' alt boyutlarında kadın katılımcıların lehine anlamlı bir şekilde farklılaşmaktadır. Araştırma sonucunda katıIımcıların bilişötesi öğrenme stratejilerinin, akademik öz-yeterliklerinin ve öğretmenliğe ilişkin tutumlarının sınıf değişkenine göre anlamlı bir şekilde farklılaşmadığı tespit edilmiştir. Diğer taraftan katılımcıların BÖSÖ, AÖYÖ ve ÖiTÖ puanları arasındaki korelasyon katsayıları pozitif yönde ve düşük, orta ve yüksek düzeylerde anlamlı bulunmuştur.

\section{Anahtar Kelimeler}

Beden eğitimi öğretmen adayı, Bilişötesi öğrenme,

Akademik öz-yeterlik, Tutum beliefs and attitudes toward teaching profession based on gender, significant differences were found in between some of the subscales of the MLSS. The scores of the female pre-service PE teachers were higher than male participants, and the scores of the participants from the MLSS, the ASES and the TPAS did not differ significantly regarding their grade levels. Additionally, significant positive correlations were observed between the scores of the MLSS, the ASES and the TPAS.

\section{Key Words}

Pre-service PE teacher, Metacognitive learning, Selfefficacy, Attitude

\section{Gíriş}

Öğrenme sırasında kullanılan ve kodlama sürecini etkileme amacında olan davranış ve düşünceler olarak tanımlanan öğrenme stratejileri (Weinstein ve Mayer, 1983), öğrencilerin akademik görevlerinde bilişsel olarak ilişkili oldukları yapılara verilen addır (Liem ve diğ., 2008). En yalın tanımla öğrenme stratejisi, bireyin kendi kendine öğrenmesini kolaylaştıran tekniklerin her biri olarak ifade edilmektedir (Özer, 2002). Arends (1997), belleğe yerleştirme, geri getirme gibi bilişsel stratejileri ve bilişsel stratejileri yönlendirici bilişötesi süreçleri kapsayan bu stratejilerin, öğrenenin öğrenmesini etkileyen, öğrenen tarafından kullanılan davranış ve düşünme süreçlerini de etkilediğine dikkat çekmektedir (Namlu, 2004, s. 127 'de belirtildiği gibi). İlk olarak Flavell (1979) tarafından kullanılan bilişötesi kavramı ise, bilişsel işlemleri ve çıktıları ya da onlarla ilgili herhangi bir şey hakkındaki, diğer bir deyişle bireyin nasıl öğrendiğine yönelik bilgisi olarak ifade edilmektedir (Baykara, 2011, s. 80'de belirtildiği gibi). Öğrenme stratejileri, öğrencinin bilgiyi işleyerek kalıcı biçimde öğrenmesini hedeflerken (Namlu, 2004), bilişötesi bilgisi ise bu öğrenmeyi kolaylaştırmayı hedeflemektedir (Baykara, 2011). Bu bağlamda Weinstein ve Mayer (1986), bir öğrenme stratejisinin amacını, öğrenenin duyuşsal durumunu etkilemek ya da

yeni bilgiyi seçme, edinme, örgütleme ve bütünleştirmesine kolaylık sağlama şeklinde açıklamaktadır (Belet ve Yaşar, 2007, s.72). Ayrıca bu amaçlar arasında öğrencinin bilgiyi anlamlandırması, örgütlemesi, sınıflaması, kopyalaması ve bilgiye motive olmasına yardımcı olacak özel teknik ve yöntemlerin öğrencilere kazandırılması gibi önemli unsurlar da yer almaktadır. Öğrenmenin doğumdan ölüme kadar devam eden bir süreç olması, öğrenme stratejilerine duyulan intiyacın hayat boyu devam etmesini kaçınılmaz kılmaktadır. Diğer yandan bilginin hızla artan ve değişen dinamik yapısı, öğrenme stratejilerinin önemine başka bir anlam kazandırmaktadır (Efe ve diğ., 2009).

Son yıllarda 'öz-yeterlik' kavramı da özellikle öğrencilerin akademik yaşantıları bağlamında sıkça incelenen bir konu olmuştur (Çapri ve Çelikkaleli, 2008; Fırat Durdukoca, 2010). Bandura (1994) öz-yeterlik inancını; bireylerin çeşitli durumlarda performanslarını ortaya koyma yeterliklerine ilişkin inançları ve bireyin, belirlenen amaçlara erişmek için eylemleri gerçekleştirme ve düzenleme yeterliklerine ilişkin kişisel yargıIarı olarak tanımlarken, Sharp ve diğ. (2002)'ne göre ise öz-yeterlik inancl, bireyin güdülenme düzeyi ve kişisel başarılarının temelini oluşturmaktadır. Çünkü bireyin yaşamındaki güçlüklere 
karşı durma ve tepki gösterme konusunda harekete geçebilmesi, eylemlerinin istediği sonuçları doğuracağı inancına varmasıyla mümkün olabilir. Bandura (1986), eğer bireyde yeterli düzeyde yetenek ve güdülenme varsa, bireyin göreve başlama ve görevi devam ettirme konusunda kararlı olacağını ifade etmektedir (Akbay, 2009, s. 25). Nitekim öz-yeterlik yargıları özellikle, gelecekte yapılacak işleri ortaya koymakta ve belirlenen etkinlikleri gerçekleştirmeden önce yapılmaktadır (Zimmerman, 2000). Öz-yeterlik inançları, bir taraftan bireyin; bilişsel, güdüsel, duyuşsal ve karar alma süreçlerinin işleyiş̧inde önemli rol oynarken diğer taraftan bu inançlar; bireyin kendini geliştirmesini, güçlükler karşısında direnç göstermesini, duygusal yaşam kalitesini ve güdülenme düzeyini arttırmasını da sağlamaktadır (Bandura, 1994, 2002). Akademik öz-yeterlik kavramı ise, öğrencinin bireysel olarak akademik bir işi başarıyla tamamlayabileceğine yönelik var olan inancı olarak tanımlanmaktadır (Zimmerman, 2000). Buradan hareketle, öz-yeterlik inancı yüksek olan bireylerin, düşük öz-yeterlik seviyesine sahip olan bireylere göre öğrenme yaşantılarındaki etkinliklerinde daha istekli oldukları, etkinliklerine yönelik daha fazla çaba harcadıkları ve karşılaştıkları güçlükler karşısında daha etkin stratejiler geliştirebildikleri bilinmektedir (Eggen ve Kauchak, 1997).

Senemoğlu (2001)'na göre, öğretmenlik mesleğinde başarılı olmak için sahip olunan yeterliklerin yanı sıra bu mesleği severek ve isteyerek yapmak da çok önemlidir. Bu durum öğretmenlerin mesleklerine karşı taşıdıkları olumlu tutumla yakından ilişkilidir. Kağıtçıbaşı (1988) tutumu; bir bireye ait ve bireye atfedilen bir eğilim olarak ifade ederken, Arkonaç (2005) ise tutumu, doğrudan gözlenemese de davranıştan önce gelen ve hareketlerimize rehberlik eden bir yapı olarak tanımlamaktadır. Genel anlamda tutum kavramı bir bireyin, herhangi bir duruma, olaylara, nesnelere, insanlara, yerlere ve fikirlere karşı lehte ya da aleyhte gerçekleştirdiği duygusal eğilim olarak belirtilmektedir (Papanastasiou, 2002; Tavşancıl, 2006). Küçükahmet (2008)'e göre öğretmenlerin öğrencileri etkileyen en önemli kişilik özelliklerinden birisi olan tutum, özellikle mesleğe, öğrenciye ve okul çalışmalarına yönelik olduğunda öğrencilerin öğrenmesine ve kişiliğine geniş ölçüde etki etmektedir. Öte yandan öğretmenliğin; bilgi ve becerilerin yanı sıra olumlu tutum ve düzenli alışkanlıkları da gerektiren bir meslek olması, okullarda öğrenim gören öğretmen adaylarının en az bilgi kadar meslekle ilgili değer ve tutum kazanmalarını da gerekli kılmaktadır (Çeliköz ve Çetin, 2004). Ayrıca Carter ve Norwood (1997)'a göre, eğitimin kalitesini artırma yönünde atılacak ilk adım olan öğretmenlik mesleğini yapanların ve öğretmen adaylarının meslekleri konusundaki inançlarının bilinmesi, öğretmen yetiştiren kurumların yöneticilerine derin bir bakış açısı kazandırmaktadır.

Konu ile ilgili araştırmalar incelendiğinde, bilişötesi öğrenme stratejileri (Baykara, 2011; Çağlayan ve diğ., 2008; Fazeli, 2012; Leutwyler, 2009; Yalız, 2010a), akademik öz-yeterlik (Adeyemo, 2007; Akbay, 2009; Alemdağ ve diğ., 2014; Chemers ve diğ., 2001; Fırat Durdukoca, 2010; Oğuz, 2012; Özsüer ve diğ., 2011; Tabancalı ve Çelik, 2013) ve öğretmenlik mesleğine yönelik tutum kavramlarının (Abbasoğlu, 2011; Akkaya, 2009; Bozdoğan ve diğ., 2007; Dabat, 2010; Jaıswal, 2013; Kaya, 2004; Pehlivan, 2010; Yalız, 2010b) ayrı ayrı ya da bu kavramların herhangi ikisinin birlikte ele alınıp çalışma konusu yapıldığı ve aralarında pozitif yönde bir ilişkinin olduğu görülmektedir (Demirtaş ve diğ., 2011; Girgin ve diğ., 2010; Küçük Kılıç ve Öncü, 2014; Sala ve Redford, 2010; Sandıkçı ve Öncü, 2013; Şen, 2006). Ancak yapılan literatür taraması sonucunda, öğretmen adayları üzerinde bu üç bağımlı değişkenin (bilişötesi öğrenme stratejileri, akademik öz-yeterlik ve öğretmenliğe yönelik tutum) bir arada çalışma konusu yapıldığı ve aralarındaki ilişkinin incelendiği herhangi bir çalışmaya rastlanılmamıştır. Bu üç bağımlı değişkenin ayrı ayrı aralarında pozitif yönde ilişsilerin (örneğin, akademik öz-yeterlik ve öğretmenliğe yönelik tutum) varlığının önceki çalışmalarda ortaya konulmuş olması, bu araştırmanın başlangıcına temel bir dayanak noktası oluşturmuştur. Diğer taraftan, gelece- 
ğin nitelikli bireylerinin yetiştirilmesinin bugünün nitelikli öğretmenlerinin yetişmesine bağlı olması (Fırat Durdukoca, 2010) ve bir eğitim sisteminin amaçlarına ulaşmasında diğer öğretmenler gibi beden eğitimi öğretmenlerinin de önemli bir yerinin olması (Darst ve Pangrazi, 2009), beden eğitimi öğretmen adaylarının da bilişötesi öğrenme stratejileri, akademik özyeterlikleri ve öğretmenlik mesleğine yönelik tutumlarının incelenmesi gerekliliğini gündeme getirmektedir. Bu nedenle araştırmadan elde edilen sonuçların, başta beden eğitimi öğretmen adaylarının bilişötesi öğrenme stratejileri, akademik öz-yeterlikleri ve öğretmenliğe yönelik tutumları arasındaki ilişkinin ortaya konulması, öte yandan öğretmen eğitimi programları ve öğrenci profilini değerlendirme noktasında literatüre katkı sağlayacağı öngörülmektedir.

Buradan hareketle bu araştırmanın amacı; beden eğitimi öğretmen adaylarının bilişötesi öğrenme stratejilerini, akademik öz-yeterlik algılarını ve öğretmenlik mesleğine yönelik tutumIarını bazı değişkenlere göre incelemek ve aralarındaki ilişkiyi belirlemektir. Bu amaçla aşağıdaki sorulara yanıt aranacaktır: 1- Beden eğitimi öğretmen adaylarının bilişötesi öğrenme stratejileri, akademik öz-yeterlikleri ve öğretmenlik mesleğine yönelik tutumları ne düzeydedir? 2- Beden eğitimi öğretmen adaylarının bilişötesi öğrenme stratejileri, akademik öz-yeterlikleri ve öğretmenlik mesleğine yönelik tutumları cinsiyet değişkenine göre anlamlı bir farklıık göstermekte midir? 3- Beden eğitimi öğretmen adaylarının bilişötesi öğrenme stratejileri, akademik öz-yeterlikleri ve öğretmenlik mesleğine yönelik tutumları sınıf değişkenine göre anlamlı bir farklılık göstermekte midir? 4- Beden eğitimi öğretmen adaylarının bilişötesi öğrenme stratejileri, akademik öz-yeterlikleri ve öğretmenlik mesleğine yönelik tutumları arasında anlamlı bir ilişki var mıdır?

\section{YÖNTEM}

Araştırmada, sosyal bilimlerde yaygın olarak kullanılan, geniş gruplar üzerinde yürütülen, gruptaki bireylerin bir olgu veya olayla ilgili or- tak görüşlerinin, tutumlarının alındığı ve olgu ve olayların betimlenmeye çalışıldığı tarama yöntemi kullanılmıştır (Karakaya, 2012). Amacı geçmişte ya da halen var olan durumu var olduğu şekliyle betimlemek olan (Kuzu, 2013) bu yöntemde önemli olan, araştırmaya konu olan olayı, bireyi ya da nesneyi kendi koşulları içinde olduğu gibi tanımlayabilmek ve mevcut durumu değiştirmeye kalkmadan gözleyebilmektir (Karasar, 2012). Araştırmada veri toplama tekniği olarak ise tarama yöntemi içerisinde sıkça kullanılan anket tekniği kullanılmıştır (Nachmias ve Nachmias, 1996).

Araştırma Grubu: Araştırmanın çalışma grubunu, 2013-2014 Eğitim-Öğretim Yılı Güz Yarıyılında, dört farklı devlet üniversitesinin $\mathrm{Be}$ den Eğitimi ve Spor Öğretmenliği Bölümü'nde öğrenim gören 248'i kadın (Ort ${ }_{\text {Yas }}=20.42 \pm 1.76$ ) ve 362 'si erkek (Ort ${ }_{\text {Yass }}=21.58 \pm 2.68$ ) 610 beden eğitimi öğretmen adayı oluşturmuştur.

Veri Toplama Araçları: Araştırmada, 'Kişisel Bilgi Formu', 'Bilişötesi Öğrenme Stratejileri Ölçeği', 'Akademik Öz-Yeterlik Ölçeği' ve 'Öğretmenliğe İlişkin Tutum Ölçeği' veri toplama aracı olarak kullanılmıştır.

Kişisel Bilgi Formu: Araştırmacılar tarafından geliştirilen 'Kişisel Bilgi Formu'; araştırmaya konu olan Beden Eğitimi ve Spor Öğretmenliği Bölümü'nde öğrenim gören beden eğitimi öğretmen adayları hakkında bilgi toplamak amacıyla cinsiyet, üniversite ve sınıf değişkenleriyle ilgili sorulardan oluşmaktadır.

Bilişötesi öğrenme Stratejileri ölçeği (Bösö): Katılımcıların, bilişötesi öğrenme stratejilerini belirlemede, Namlu (2004) tarafından geliştirilen 'Bilişötesi Öğrenme Stratejileri Ölçeği' kullanılmıştır. 21 maddeden oluşan ölçek, bireyin kendi biliş sistemi, yapısı ve çalışması hakkındaki bilgisi olarak tanımlanan bilişötesi öğrenme stratejilerinin alt boyutlarını belirlemede kullanılan bir ölçme aracıdır. Geçerlik ve güvenirlik çalışması üniversite öğrencileri üzerinde gerçekleştirilen ölçek; 4'lü Likert tipinde hazırlanmış, puanlama da buna göre yapılmıştır. Likert seçenekleri "Hiçbir Zaman", "Bazen", "Sık Sık" ve "Her Zaman" şeklinde sıralanmış; 1, 
2,3 ve 4 şeklinde puanlanmıştır. 4 faktörlü bir yapıya sahip olan ölçeğin faktörleri, 'Planlama Stratejileri (6 madde)', 'Örgütleme Stratejileri (6 madde)', 'Denetleme Stratejileri (5 madde)' ve 'Değerlendirme Stratejileri (4 madde)' şeklindedir. Ölçekten alınabilecek en düşük puan 21 , en yüksek puan ise 84 'dür. Ölçeğin Cronbach Alpha iç tutarlık katsayısı 0.81 olarak hesaplanmıştır. Bu araştırma kapsamında toplanan veriler üzerinde de ölçeğin geçerlik ve güvenirliği, araştırmacılar tarafından yeniden incelemiştir. Cronbach Alpha iç tutarlık katsayısı 0.88 olarak hesaplanırken ölçeğin faktör yapısı ise AMOS 18 programı kullanılarak doğrulayıcı faktör analizi ile test edilmiş ve uyum indeksi değerleri $\left(\chi^{2} / \mathrm{sd}=2.61, \mathrm{CFI}=0.93, \mathrm{GFI}=0.93, \mathrm{NFI}=0.90\right.$, TLI=0.92, SRMR=0.05 ve RMSEA=0.05), ölçeğin tek faktörlü yapısının çalışma grubu için doğrulandığını göstermiştir.

Akademik Öz-Yeterlik ölçeği (AÖYö): Jerusalem ve Schwarzer (1981) tarafından geliştirilen, Yılmaz, Gürçay ve Ekici (2007) tarafından üniversite öğrencileri üzerinde Türkçe uyarlaması yapılan ölçek, 7 maddeden oluşmaktadır. Ölçekte yer alan maddeler, 4'lü Likert tipi ölçek (Bana Hiç Uymuyor, Bana Çok Az Uyuyor, Bana Uyuyor, Bana Tamamen Uyuyor) formundadır. Ölçeğin Cronbach Alpha iç tutarlılık katsayısı 0.79 olarak tespit edilmiştir. Ölçekten alınabilecek en düşük puan 7 ve en yüksek puan ise 28'dir. Bu araştırma kapsamında toplanan veriler üzerinde de ölçeğin geçerlik ve güvenirliği, araştırmacılar tarafından yeniden incelemiştir. Cronbach Alpha iç tutarlık katsayısı 0.76 olarak hesaplanırken ölçeğin faktör yapısı ise AMOS 18 programı kullanılarak doğrulayıcı faktör analizi ile test edilmiş ve uyum indeksi değerleri $\left(\chi^{2} / \mathrm{sd}=1.85, \mathrm{CFI}=0.99, \mathrm{GFI}=0.99, \mathrm{NFI}=0.98\right.$, $\mathrm{TLI}=0.98, \mathrm{SRMR}=0.03$ ve RMSEA=0.04), ölçeğin tek faktörlü yapısının çalışma grubu için doğrulandığını göstermiştir.

Öğretmenliğe İlişkin Tutum ölçeği (öiTö):

Erkuş ve diğ. (2000) tarafından, öğretmen adayIarının öğretmenlik mesleğine yönelik tutumlarını belirlemek amacıyla geliştirilen 'Öğretmenliğe IIlişkin Tutum Ölçeği' 22 maddeden oluş- maktadır. Ölçek maddeleri; (1) "Bana Hiç Uygun Değil", (2) Bana Uygun Değil, (3) Kararsızım, (4) Bana Uygun ve (5) Bana Tamamen Uygun biçiminde puanlanmaktadır. Ölçeğin Cronbach Alpha iç tutarlık katsayısı 0.99 olarak hesaplanmış; ölçeğin öğretmen adayları ile aday olmayanları ayırt ettiği ve bu haliyle geçerli bir ölçek olduğu rapor edilmiştir. Ölçekten alınabilecek en düşük puan 22 ve en yüksek puan ise 110'dur. Bu araştırma kapsamında toplanan veriler üzerinde de ölçeğin geçerlik ve güvenirliği, araştırmacılar tarafından yeniden incelemiştir. Cronbach Alpha iç tutarlık katsayısı 0.95 olarak hesaplanırken ölçeğin faktör yapısı ise AMOS 18 programı kullanılarak doğrulayıcı faktör analizi ile test edilmiş ve uyum indeksi değerleri $\left(\chi^{2} / \mathrm{sd}=3.36, \mathrm{CFI}=0.95\right.$, $\mathrm{GFI}=0.91, \mathrm{NFI}=0.93, \mathrm{TLI}=0.94, \mathrm{SRMR}=0.05$ ve RMSEA=0.06), ölçeğin tek faktörlü yapısının çaIışma grubu için doğrulandığını göstermiştir.

Verilerin Toplanması: Araştırmada kullanıIan veri toplama araçları, 2013-2014 Eğitim-Öğretim Yılı Güz Yarıyılında, uygulama yapılacak üniversitelerin ilgili birimlerinden gerekli izinlerin alınmasını takiben çalışma grubunu oluşturan öğretmen adaylarına uygulanmıştır. Araştırmacılar tarafından toplanan formlar kontrol edilerek eksik veya yanlış doldurulanlar araştırma dışında tutulmuştur. Daha sonra öğrencilere uygulanan anketlerin geçerli ve kabul edilebilir nitelikte olanları, kodlanarak bilgisayar ortamına aktarılmıştır.

Verilerin Analizi: Verilerin değerlendirilmesinde istatistiki yöntem olarak; frekans, aritmetik ortalama, standart sapma; t-testi, tek faktörlü MANOVA, tek yönlü varyans analizi (ANOVA), Tukey çoklu karşılaştırma ve Pearson Correlation testleri kullanılmıştır. Verilerin parametrik testlerin ön şartlarını sağlayıp sağlamadığına Çarpıklık ve Basıkıı (normal dağılım durumu) değerleri, Box M (varyans-kovaryans matrislerinin homojenliği) ve Levene (varyansların eşitliği) testi sonuçları incelenerek karar verilmiştir (Büyüköztürk, 2012). Kline (2005), Çarpıklık değerinin \pm 3 ve Basıklık değerinin de \pm 10 sınırları içerisinde olmasının, verilerin normal dağıımının bir göstergesi olarak değerlendirilebileceği- 
ni belirtmektedir. Öte yandan Box M ve Levene testi ile hesaplanan $\mathrm{F}$ değerlerinin de manidar olmaması ( $p>0.05$ ) ile varyans-kovaryans matrislerinin homojenliği ve varyansların eşitliği sayıltılarının karşılanacağı belirtilmektedir (Çokluk ve diğ., 2010). Analizler, verilerin parametrik test varsayımlarını karşıladığını göstermiştir. Ölçeklerin faktör yapılarını doğrulamak için doğrulayıcı faktör analizi (McIntire ve Miller, 2000), güvenirliklerini belirlemek için ise Cronbach Alpha iç tutarlık katsayıları hesaplanmıştır (Cronbach, 1951). Sümer (2000), doğrulayıcı faktör analizinde uyum indeksi değerlerinin $\chi^{2} /$ sd için $\leq 5$; CFI, GFI, NFI ve TLI için $\geq 0.90$; SRMR ve RMSEA için $\leq 0.08$ olmasının iyi uyuma işaret ettiğini belirtmektedir (Çokluk ve diğ., 2010). Güvenirlik katsayısının da 0.70 ve daha yüksek olması, test puanlarının güvenirliği için genel olarak yeterli görünmektedir (Carter, 1997).

\section{BULGULAR}

Katılımcıların; BÖSÖ, AÖYÖ ve ÖiTÖ'nden aldıkIarı toplam puanların aritmetik ortalaması sırasıyla 56.35, 21.58 ve 93.72'dir. BÖSÖ puanları faktör bazında incelendiğinde en düşük ortalamanın 'Planlama' boyutunda (15.34/6=2.56), en yüksek ortalamanın da 'Denetleme' boyutunda (14.49/5=2.90) olduğu görülmektedir (Tablo 1).

MANOVA sonuçları, cinsiyet değişkeninin BÖSÖ alt faktörleri üzerindeki temel etkisinin anlamlı olduğunu göstermektedir ( $\lambda=0.98$, $\left.F_{(4,605)}=3.67, p=0.006\right)$. Hangi bağımlı değişkenin çok değişkenli anlamlılığa katkı sağladığını anlamak amacıyla yapılan ANOVA sonuçlarına göre de cinsiyet ana etkisi açısından 'Planlama' $\left(F_{(1,608)}=13.28, p=0.001\right)$ 'Örgütleme' $\left(F_{(1,608)}=6.39\right.$, $p=0.000)$ ve 'Denetleme' $\left(F_{(1,608)}=4.69, p=0.031\right)$ faktör puanlarının anlamlı olarak farklılaştığı sonucuna ulaşılmıştır. 'Değerlendirme' boyutunda ise anlamlı bir farklılık tespit edilmemiş-

Tablo 1. Ölçek puanlarının dağılımı

\begin{tabular}{lllcc}
\hline Ölçek & $\mathbf{N}$ & Ort $\pm \mathbf{S s}$ & Çarpıklık & Basıklık \\
\hline Bösö & 610 & $56.35 \pm 10.16$ & 0.04 & 0.05 \\
Planlama & 610 & $15.34 \pm 3.47$ & -0.15 & 0.03 \\
Örgütleme & 610 & $16.12 \pm 4.11$ & -0.06 & -0.35 \\
Denetleme & 610 & $14.49 \pm 3.15$ & -0.21 & -0.26 \\
Değerlendirme & 610 & $10.40 \pm 2.52$ & 0.05 & -0.23 \\
AöYö & 610 & $21.58 \pm 3.39$ & -0.22 & -0.06 \\
Öiтö & 610 & $93.72 \pm 15.71$ & -1.35 & 1.71
\end{tabular}

Tablo 2. Cinsiyete göre ölçek puanlarının dağılımı

\begin{tabular}{lcc}
\hline Ölçek & $\begin{array}{c}\text { Kadın }(n=248) \\
\text { Ort } \pm \text { Ss }\end{array}$ & $\begin{array}{c}\text { Erkek }(n=362) \\
\text { Ort } \pm \text { Ss }\end{array}$ \\
\hline BÖsö & $58.00 \pm 10.25$ & $55.22 \pm 9.96$ \\
Planlama & $15.95 \pm 3.40$ & $14.92 \pm 3.46$ \\
Örgütleme & $16.63 \pm 4.17$ & $15.78 \pm 4.03$ \\
Denetleme & $14.82 \pm 3.04$ & $14.26 \pm 3.20$ \\
Değerlendirme & $10.60 \pm 2.54$ & $10.26 \pm 2.49$ \\
AÖYö & $21.59 \pm 3.23$ & $21.58 \pm 3.50$ \\
öiтö & $94.44 \pm 16.07$ & $93.24 \pm 15.46$ \\
\hline
\end{tabular}


Tablo 3. Sınıfa göre ölçek puanlarının dağılımı

\begin{tabular}{lcccc}
\hline Ölçek & $\begin{array}{c}\text { 1.Sınıf }(n=176) \\
\text { Ort } \pm \text { Ss }\end{array}$ & $\begin{array}{c}\text { 2.Sınıf }(n=164) \\
\text { Ort } \pm \text { Ss }\end{array}$ & $\begin{array}{c}\text { 3.Sınıf }(n=169) \\
\text { Ort } \pm \text { Ss }\end{array}$ & $\begin{array}{c}\text { 4.Sınıf }(n=101) \\
\text { Ort } \pm \text { Ss }\end{array}$ \\
\hline Bösö & $55.81 \pm 9.99$ & $56.01 \pm 10.30$ & $56.56 \pm 10.48$ & $57.51 \pm 9.71$ \\
Planlama & $15.30 \pm 3.61$ & $14.98 \pm 3.51$ & $15.35 \pm 3.39$ & $15.97 \pm 3.39$ \\
Örgütleme & $15.80 \pm 4.18$ & $15.98 \pm 3.88$ & $16.32 \pm 4.34$ & $16.61 \pm 3.96$ \\
Denetleme & $14.42 \pm 2.99$ & $14.67 \pm 3.15$ & $14.30 \pm 3.27$ & $14.63 \pm 3.22$ \\
Değerlendirme & $10.29 \pm 2.48$ & $10.38 \pm 2.51$ & $10.59 \pm 2.53$ & $10.30 \pm 2.58$ \\
AöYö & $21.30 \pm 3.54$ & $21.43 \pm 3.37$ & $21.58 \pm 3.35$ & $22.35 \pm 3.16$ \\
Öiтö & $94.15 \pm 15.24$ & $91.67 \pm 17.82$ & $94.76 \pm 13.33$ & $94.57 \pm 16.47$ \\
\hline
\end{tabular}

Tablo 4. BÖSÖ, AÖYÖ ve ÖiTÖ puanları arasındaki korelasyon sonuçları

\begin{tabular}{lccccccc}
\hline & Bösö & Planlama & Örgütleme & Denetleme & Değerlendirme & AöYö Öiтö \\
\hline BÖsö & 1 & & & & & & \\
Planlama & $0.73^{* *}$ & 1 & & & & & \\
Örgütleme & $0.85^{* *}$ & $0.50^{* *}$ & 1 & & & & \\
Denetleme & $0.76^{* *}$ & $0.31^{* *}$ & $0.55^{* *}$ & 1 & & & \\
Değerlendirme & $0.70^{* *}$ & $0.38^{* *}$ & $0.42^{* *}$ & $0.48^{* *}$ & 1 & 1 & \\
AöYö & $0.41^{* *}$ & $0.27^{* *}$ & $0.33^{* *}$ & $0.39^{* *}$ & $0.28^{* *}$ & 1 \\
Öiтö & $0.22^{* *}$ & $0.17^{* *}$ & $0.18^{* *}$ & $0.21^{* *}$ & $0.09^{*}$ & $0.21^{* *}$ & 1 \\
\hline
\end{tabular}

$* p<0.05, * * p<0.01$

tir $\left(\mathrm{F}_{(1,608)}=2.60, \mathrm{p}=0.107\right)$. Tüm alt boyutlarda kadın katılımcıların ortalama puanları erkeklerin puanlarından daha yüksektir. Katılımcıların hem AÖYÖ puanları $\left(t_{(608)}=0.06 ; p=0.949\right)$ hem de ÖiтÖ puanları $\left(t_{(608)}=0.93 ; p=0.353\right)$, cinsiyet değişkenine göre anlamlı bir farklılık göstermemektedir (Tablo 2).

MANOVA sonuçları, sınıf değişkeninin BÖsÖ alt faktörleri üzerindeki temel etkisinin anlamlı olmadığını $\left(\lambda=0.98, F_{(4,603)}=1.22, p=0.265\right)$ göstermektedir. Faktör düzeyinde de 'Planlama' $\left(F_{(3,606)}=1.72, p=0.161\right)$, 'Örgütleme' $\left(F_{(3,606)}=1.04\right.$, $p=0.374)$ 'Denetleme' $\left(F_{(3,606)}=0.49, p=0.689\right)$ ve 'Değerlendirme' $\left(F_{(3,606)}=0.50, p=0.685\right)$ faktör puanlarının anlamlı olarak farklılaşmadığı sonucuna ulaşılmıştır. Katılımcıların hem AÖYÖ puanIarı $\left(F_{(3,606)}=2.26, p=0.081\right)$ hem de ÖiTÖ puanla$\mathrm{rI}\left(\mathrm{F}_{(3,606)}=1.32, p=0.267\right)$, sınıf değişkenine göre anlamlı bir farklılık göstermemektedir (Tablo 3).
Katıımcıların BÖSÖ, AÖYÖ ve ÖITÖ puanları arasındaki korelasyon katsayıları pozitif yönde ve düşük, orta ve yüksek düzeylerde anlamlı bulunmuştur (Tablo 4).

\section{TARTIŞMA}

Araştırmadan elde edilen bulgulara göre beden eğitimi öğretmen adaylarının bilişötesi öğrenme stratejilerinin orta seviyede olması literatürdeki bazı çalışmaların sonuçlarıyla paralellik göster mektedir (Baykara, 2011; Kartal ve diğ., 2013; Küçük Kılıç ve Öncü, 2014; Şara, 2012). Bazı araştırmalarda katılımcıların bilişötesi öğrenme stratejilerinin yüksek düzeyde olduğu belirtilirken (Sağlam, 1999; Vural, 2011), bazılarında ise katıımcıların bilişötesi öğrenme strateji düzeylerinin oldukça düşük olduğu tespit edilmiştir (Dural, 2008). Şara (2012)'ya göre öğretmen adaylarının bilişötesi öğrenme stratejilerinin 
orta seviyede olması, öğretmenlik eğitimi boyunca yapılan ezbere dayalı sınav ve etkinliklerden kaynaklanıyor olabilir. Bu sonuç ayrıca, öğrencilerin nasıl öğrendiklerine ilişkin güçlü ve zayıf yönlerini bildikleri, karmaşık görevleri yerine getirebilmede gerekli olan bilgi ve becerilere sahip oldukları ayrıca bu bilgi ve becerileri nasıl kullanacakları hakkında yeterli bilişsel beceriye sahip oldukları şeklinde de yorumlanabilir.

Beden eğitimi öğretmen adaylarının akademik öz-yeterlik düzeylerinin orta seviyenin üzerinde olması Alemdağ ve diğ. (2014), Er ve Gürgan (2011) ve Küçük Kılıç ve Öncü (2014) tarafından yapılan çalışmanın sonucuyla benzerlik göstermektedir. Diğer taraftan Oğuz (2012), Sandıkçı ve Öncü (2013) ve Tabancalı ve Çelik (2013) tarafından yapılan çalışmalarda, katıımcıların öz-yeterlik düzeylerinin yüksek olduğu tespit edilmiştir. Bu sonuç, öğrencilerin üniversite eğitimine başlamadan önceki süreçte sporun içinde yer almalarından ve sahip oldukları bu bilgi ve yeterlikleri öğrenim gördükleri bölümden dolayı akademik ortama olumlu transfer edebilmelerinden kaynaklanmış olabilir.

Araştırma sonuçları, birçok çalışmada (Abbasoğlu, 2011; Aksoy, 2010; Özder ve diğ., 2010; Sandıkçı ve Öncü, 2013; Yalız, 2010b) elde edilen sonuçlara paralel olarak beden eğitimi öğretmen adaylarının öğretmenlik mesleğine yönelik tutumlarının yüksek düzeyde olduğunu göstermektedir. Tutumun, davranışlara etki ederek, davranışları yönlendirdiği dolayısıyla bireyin, tutumu ile paralel davranışlar sergileme olasılığının bulunduğu belirtilmektedir (Toprak ve Saraç, 2014). Bu bağlamda, öğrencilerin bu bölüme yerleşebilmek için çaba sarf etmeleri ve özel yetenek sınavı gibi zorlu aşamaları geride bırakmaları, bu konuda tutumlarının yüksek olduğunun göstergesi olabilir. Toprak ve Saraç (2014) tarafından yapılan çalışmanın sonucunda beden eğitimi öğretmeni aday adaylarının öğretmenlik mesleğine yönelik tutumlarının yüksek çıkması da bu yorumu destekler niteliktedir.

Cinsiyet değişkenine göre katılımcıların BÖSÖ puanları incelendiğinde 'Planlama', 'Örgütleme' ve 'Denetleme' alt boyutlarında kadın katılımcılar lehine anlamlı farklılıkların olduğu görülmekle birlikte tüm alt boyutlarda kadın katılımcıların ortalama puanlarının erkeklerin puanlarından daha yüksek olduğu tespit edilmiştir. Bu bulgulara paralel olarak, bazı çalışmalarda (Baykara, 2011; Dural 2008; Efe ve diğ., 2009; iflazoğlu Saban ve Tümkaya, 2008; Kartal ve diğ., 2013; Leutwyler, 2009; Şara, 2012; Şen, 2006; Yalız, 2010a) kadın katılımcıların bilişötesi öğrenme stratejilerinin erkeklerden daha yüksek olduğu tespit edilmiştir. Bu durum, kadın öğretmen adaylarının öğrenme sürecini daha planlı ve derinlemesine incelemesinden kaynaklanıyor olabilir (Efe ve diğ., 2009). Diğer taraftan Bayındır (2006), Okçu ve Kahyaoğlu (2007) ve Uyar (2008), yaptıkları çalışmalarda cinsiyet ile öğrenme stratejileri arasında anlamlı bir fakın olmadığını belirtirken, Küçük Kılıç ve Öncü (2014) yaptıkları çalışmada, bilişötesi öğrenme stratejilerinin cinsiyet değişkenine göre erkeklerin lehine farklılaştığını tespit etmişlerdir. Bu sonuç, kadınların sosyal rollerinden dolayı daha planlı, daha aktif ve süreci daha etkin kullanmak durumunda olmaları ve bu durumun öğrenme sürecine yansıtılmış olmasından kaynaklanabilir. Ayrıca erkek öğrencilerin genellikle dikkatlice incelemeden bilgiyi kopya etmelerinden veya ne için uğraştıklarını ve bu bilgiyi daha sonra nasıl kullanabileceklerini bilmeden pasif öğrenme yoluna gitmelerinden kaynaklanıyor olabilir.

Araştırmadan elde edilen bulgulara göre katılımcıların AÖYÖ'den aldıkları puanlar, cinsiyet değişkenine göre anlamlı bir farklılık göstermemektedir. Bu sonuç literatürde bazı araştırma sonuçlarıyla paralellik göstermektedir (Alemdağ ve diğ., 2014; Çakır ve diğ., 2006; Küçük Kılıç ve Öncü 2014; Oğuz, 2012; Özsüer ve diğ., 2011; Tabancalı ve Çelik, 2013). Bu bulgu, beden eğitimi ve spor yüksekokulu öğrencilerinin sahip oldukları sporcu kimliğinden kaynaklanıyor olabilir (Küçük Kılıç ve Öncü, 2014). Diğer taraftan Er ve Gürgan (2011) yaptıkları çalışmada, kadın katıımcıların akademik öz-yeterlik inanç düzeylerinin erkeklere göre daha yüksek olduğunu belirtirken, Akbay (2009) ve Firat Durdukoca (2010) yaptıkları çalışmada ise erkek katılımcı- 
Iarın daha yüksek akademik öz-yeterliğe sahip olduğunu belirtmişlerdir.

Araştırma sonuçları, birçok çalışmada (Abbasoğlu, 2011; Bulut, 2009; Çapa ve Çil, 2000; Dabat, 2010; Demirtaş ve diğ., 2011; Durmuşoğlu ve diğ., 2009; Jaıswal, 2013; Kaya, 2004; Korkmaz ve Usta, 2010; Murat ve diğ., 2010; Özder ve diğ., 2010; Sandıkçı ve Öncü, 2013) elde edilen sonuçlara paralel olarak öğretmenlik mesleğine yönelik tutumlarının cinsiyet değişkeni açısından anlamlı bir şekilde farklılaşmadığını göstermektedir. Beden eğitimi öğretmen adayları üzerinde yapılan bu çalışmada, cinsiyete göre anlamlı bir farklılığın olmaması, beden eğitimi ve spor öğretmenliği bölümünün kendine has özel bir yapıya sahip olmasından kaynaklanmış olabilir. Öte yandan ulaşılan bu farklı sonuçlar, cinsiyet değişkeni ile ilgili genellemelerden kaçınılması gereğini de gündeme getirmektedir (Sandıkçı ve Öncü, 2013).

Araştırma sonucunda beden eğitimi öğretmen adaylarının bilişötesi öğrenme stratejileri ile sınıf değişkeni arasında anlamlı bir farklılık tespit edilmemiştir. Benzer şekilde, bazı araştırmalar (Baykara, 2011; Çağlayan ve diğ., 2008; Efe ve diğ., 2009; Küçük Kılıç ve Öncü, 2014; Şen, 2006; Yalız, 2010a) sonucunda da bilişötesi öğrenme stratejileri ile sınıf değişkeni arasındaki farkın önemsiz olduğu sonucuna ulaşılmıştır. Araştırmadan elde edilen bu bulgu, öğrencilerin kendi öğrenmelerini düzenleyebilecek yeterlikte olmalarından kaynaklanabileceği gibi öğrencilerin sistemli ders çalışma alışkanlığını ortaöğretim düzeyinde kazanmış olmalarından da kaynaklanabilir (Küçük Kılıç ve Öncü, 2014). Birçok araştırmada bilişötesi becerilerin yaşla ve öğrenme deneyimiyle doğru orantılı olarak geliştiği (Akın ve Abacı, 2011), ayrıca bilişötesi bilginin erken yaşlarda belirdiği, yavaşça geliştiği ve en azından ergenlik döneminin sonuna kadar gelişimini sürdürdüğü ifade edilmektedir (Alexander, Carr ve Schwanenflugel, 1995). Bu bağlamda katıımcıların bilişötesi öğrenme stratejilerinin sınıf düzeyine göre değişmemesi, katılımcıların ergenlik dönemini geride bırakmaları, üniversite öğrenimine kadar yeterince öğrenme deneyimi kazanmış olmaları dolayısıyla öğrencilerin kendi düşünme süreçleri hakkında düşünme, verimli öğrenme stratejilerini bilme ve bunları yönetme gibi becerileri hâlihazırda kazanmış olmalarından kaynaklanabilir.

Beden eğitimi öğretmen adaylarının akademik öz-yeterlik inanç düzeylerinin sınıf değişkeni açısından anlamlı farklılık göstermemesi Küçük Kılıç ve Öncü (2014) tarafından yapılan çalışmanın sonucuyla benzerlik göstermektedir. Er ve Gürgan (2011) ve Oğuz (2012) yaptıkları çalışmada akademik öz-yeterlik inanç düzeyinin sınıf değişkeni açısından dördüncü sınıf lehine farklıIaştığını belirtirken, Alemdağ ve diğ. (2014) tarafından yapılan çalışmanın sonucunda ise akademik öz-yeterlik algısının üçüncü sınıfta öğrenim gören katılımcıların lehine anlamlı bir şekilde farklılaştığı tespit edilmiştir. Beden eğitimi öğretmen adaylarının akademik öz-yeterlik inanç düzeylerinin sınıf değişkeni açısından anlamlı farklılık göstermemesinin nedeni olarak beden eğitimi ve spor yüksekokulu öğrencilerinin öğrenimin her kademesinde sürece aktif olarak katılmaları gösterilebilir (Küçük Kılıç ve Öncü, 2014).

Araştırmadan elde edilen bulgulara göre beden eğitimi öğretmen adaylarının öğretmenlik mesleğine yönelik tutumları, sınıf değişkenine göre anlamlı bir farklılık göstermemektedir. Benzer şekilde, Abbasoğlu (2011), Durmuşoğlu ve diğ. (2009), Gökçe ve Sezer (2012), Özder ve diğ. (2010), Saracaloğlu (1992), Şen (2006), Yalız (2010b), tarafından yapılan çalışmalarda öğretmenlik mesleğine yönelik tutumun sınıf değişkeni açısından anlamlı bir şekilde farklıIaşmadığı tespit edilmiş̧ir. Bu durumun nedeni olarak beden eğitimi öğretmen adaylarının öğrenim gördükleri bölümü isteyerek seçmeleri ve bu bölüme girerken zorlu aşamaları (özel yetenek sınavı) geride bırakmaları gösterilebilir. Diğer taraftan Kaya (2004) tarafından yapılan çalışmanın sonucuna göre öğretmen adaylarının sınıf düzeyleri yükseldikçe öğretmenlik mesleğine yönelik tutumları olumsuz yönde gelişme göstermektedir. Benzer şekilde Pehlivan (2010) tarafından yapılan çalışmanın sonucunda öğretmenlik mesleğine yönelik tutumun son sınıfta 
anlamlı bir biçimde azaldığı tespit edilmiştir.

Araştırmadan elde edilen bir diğer sonuç; katılımcıların bilişötesi öğrenme stratejileri ölçeği, akademik öz-yeterlik ölçeği ve öğretmenliğe ilişkin tutum ölçeği puanları arasındaki korelasyon katsayılarının pozitif yönde ve düşük, orta ve yüksek düzeylerde anlamlı olduğudur. Yüksek akademik öz-yeterliğe sahip kişilerin öğrenme stratejilerini daha etkili kullandıkları ve öğretmenlik mesleğine yönelik daha olumlu tutum geliştirdikleri söylenebilir. Sala ve Redford (2010) yaptıkları çalışmada yüksek öz-yeterliğe sahip öğrencilerin çalışma için daha stratejik yaklaşım kullandıklarını belirtirken, Küçük Kılıç ve Öncü (2014) tarafından yapılan çalışmada bilişötesi öğrenme stratejileri ve akademik özyeterlik arasında pozitif yönde korelasyonlar olduğu tespit edilmiştir. Girgin ve diğ. (2010) yaptıkları çalışmada öz-yeterlik ile öğretmenlik mesleğine yönelik tutum arasında pozitif ve anlamlı bir ilişki olduğunu; Denizoğlu (2008) ve Sandıkçı ve Öncü (2013) tarafından yapılan çaIışmada öz-yeterlik ile öğretmenlik mesleğine yönelik tutum arasında anlamlı bir ilişki olduğunu; Demirtaş ve diğ. (2011)'in yaptığı çalışmada öz-yeterlik algıları ile mesleğe yönelik tutumları arasında pozitif yönde ancak düşük düzeyde bir korelasyon olduğu tespit edilmiştir. Yüksek akademik öz-yeterliğe sahip kişilerin öğrenme stratejilerini daha etkili kullandıkları ve öğretmenlik mesleğine yönelik daha olumlu tutum geliştirdikleri söylenebilir.

\section{SONUÇ Ve ÖNERILER}

Beden eğitimi öğretmen adaylarının bilişötesi öğrenme stratejileri, akademik öz-yeterlikleri ve öğretmenlik mesleğine yönelik tutumlarını bazı değişkenlere göre incelemek ve aralarındaki ilişkiyi belirlemek amacıyla yürütülen bu çalışma sonucunda araştırma grubunun bilişötesi öğrenme strateji düzeylerinin orta seviyede, akademik öz-yeterlik algılarının orta seviyenin üzerinde, öğretmenlik mesleğine ilişkin tutumlarının da yüksek seviyede olduğu görülmektedir. Araştırma sonucunda akademik öz-yeterlik ile öğretmenlik mesleğine yönelik tutum dü- zeyinin cinsiyet değişkenine göre anlamlı bir şekilde farklılaşmadığı görülürken, bilişötesi öğrenme stratejilerinin cinsiyet değişkenine göre kadın katılımcıların lehine anlamlı bir şekilde farkıılaştığı tespit edilmiştir. Katılımcıların bilişötesi öğrenme stratejilerinin, akademik özyeterliklerinin ve öğretmenliğe ilişkin tutumlarının sınıf değişkenine göre anlamlı bir şekilde farklılaşmadığı tespit edilmiştir. Diğer taraftan araştırma sonuçları, katılımcıların bilişötesi öğrenme stratejileri, akademik öz-yeterlikleri ve öğretmenliğe ilişkin tutumları arasında pozitif yönde bir ilişki olduğunu göstermektedir.

Araştırmanın, bilişötesi öğrenme stratejileri, akademik öz-yeterlik ve öğretmenlik mesleğine yönelik tutumun bir arada ele alındığı çalışma olması bakımından literatüre katkı sağlayacağı düşünülmektedir. Çalışma grubunun dört üniversitede öğrenim gören öğrencilerden oluşması araştırmanın sınırlılığı kapsamında değerlendirilebilir. Bundan sonra yapılacak çalışmalarda daha geniş örneklem gruplarına intiyaç olduğu, eğitimin kalite ve yapısı açısından diğer öğretmen adaylarının dâhil edildiği karşılaştırmalı araştırmalar planlamanın gerekli olduğu düşünülmektedir. Diğer yandan, çalışmanın nitel araştırma yaklaşımıyla planlanarak çalışmaya farklı bir boyut kazandırılması ve öğretmen adaylarının üniversite eğitimleri boyunca bu konular kapsamında izleneceği boylamsal çalışmaların planlanması sonuçların daha kolay yorumlanabilmesi açısından önemli görülmektedir.

Yazar Notu: Bu çalışma, Karadeniz Teknik Üniversitesi Eğitim Bilimleri Enstitüsü Beden Eğitimi ve Spor Anabilim Dalı'nda yüksek lisans tezi olarak kabul edilmiş ayrıca çalışmanın özeti, $9^{\text {th }}$ FIEP Avrupa Kongresi (9-12 Ekim 2014, Sofya, Bulgaristan)'nde sözlü bildiri olarak sunulmuştur.

\section{Yazıșma Adresi (Corresponding Address):}

\section{Dr. Erman ÖNCÜ}

Karadeniz Teknik Üniversitesi Beden Eğitimi ve Spor Yüksekokulu, Trabzon

E-posta: eoncu@ktu.edu.tr

Telefon No: 04623777159

Faks No: 04622481072 


\section{K AY N A KL AR}

1. Abbasoğlu E. (2011). Beden eğitimi öğretmeni adaylarının öğretmenlik mesleğine ilişkin tutum ve benlik saygılarının incelenmesi. Yayımlanmamış Yüksek Lisans Tezi. Karadeniz Teknik Üniversitesi. Eğitim Bilimleri Enstitüsü.

2. Adeyemo DA. (2007). Moderating influence of emotional intelligence on the link between academic self-efficacy and achievement of university students. Psychology \& Developing Societies, 19(2), 199-213.

3. Akbay SE. (2009). Cinsiyete göre üniversite öğrencilerinde akademik erteleme davranışı: Akademik Güdülenme, Akademik Öz-yeterlik ve Akademik Yüklenme Stillerinin Rolü. Yayımlanmamış Yüksek Lisans Tezi. Mersin Üniversitesi. Sosyal Bilimler Enstitüsü.

4. Akın A, Abacı R. (2011). Biliş ötesi. Ankara: Nobel Akademik Yayıncılık.

5. Akkaya N. (2009). Öğretmen adaylarının öğretmenlik mesleğine yönelik tutumlarının bazı değişkenlere göre incelenmesi. Dokuz Eylül Üniversitesi Buca Eğitim Fakültesi Dergisi, 25, 35-42.

6. Aksoy ME. (2010). Öğretmen adaylarının öğretmenlik mesleğine ilişkin tutumları. Gaziosmanpaşa Üniversitesi Örneği. Sosyal Bilimler Araştırmaları Dergisi, 2, 197-212.

7. Alemdağ C, Öncü E, Yılmaz AK. (2014). Beden eğitimi öğretmeni adaylarının akademik motivasyon ve akademik öz-yeterlikleri. Spor Bilimleri Dergisi, 25(1), 23-35.

8. Alexander JM, Carr M, Schwanenflugel PJ. (1995). Development of metacognition in gifted children: Directions for future research. Developmental Review, 15, 1-37.

9. Arkonaç SA. (2005). Sosyal psikoloji. İstanbul: Alfa Basım Yayım.

10. Bandura A. (1994). Self-efficacy. (VS Ramachaudran, Ed.) Encyclopedia of human behavior. 71-81. New York: Academic Press.

11. Bandura A. (2002). Social cognitive theory in cultural context. Applied Psychology: An International Review, 51(2), 269-290.

12. Bayındır N. (2006). Öğrenme stratejilerinin öğretimi ve bilişsel süreçlere yansıması. Yayımlanmamış Doktora Tezi. Marmara Üniversitesi. Eğitim Bilimleri Enstitüsü.

13. Baykara K. (2011). Öğretmen adaylarının bilişötesi öğrenme stratejileri ile öğretmen yeterlik algıları üzerine bir çalışma. Hacettepe Üniversitesi Eğitim Fakültesi Dergisi, 40, 80-92.

14. Belet ŞD, Yaşar Ş. (2007). Öğrenme stratejilerinin okuduğunu anlama ve yazma becerileri ile Türkçe dersine ilişkin tutumlara etkisi. Eğitimde Kuram ve Uygulama, 3(1), 69-86.

15. Bozdoğan AE, Aydın D, Yııdırım K. (2007). Öğretmen adaylarının öğretmenlik mesleğine ilişkin tutumları. Ahi Evran Üniversitesi Kırşehir Eğitim Fakültesi Dergisi, 8(2), 83-97.
16. Bulut i. (2009). Öğretmen adaylarının öğretmenlik mesleğine ilişkin tutumlarının değerlendirilmesi. Dicle ve Fırat Üniversitesi Örneği. Dicle Üniversitesi Ziya Gökalp Eğitim Fakültesi Dergisi, 14, 13-24.

17. Büyüköztürk Ş. (2012). Sosyal bilimler için veri analizi el kitabı. Ankara: Pegem Akademi.

18. Carter CD. (1997). Doing quantative psychological research: from design to report. UK: Psychology Pres Ltd.

19. Carter G, Norwood KS. (1997). The relationship between teacher and student beliefs mathematics. School Science and Mathematics, 97(2), 62-67.

20. Chemers MM, Hu LT, Garcia BF. (2001). Academic selfefficacy and first year college student performance and adjusment. Journal of Educational Psychology, 93(1), 55-64.

21. Cronbach LJ. (1951). Coefficient alpha and internal structure of tests. Pyschometrica, 16, 297-334.

22. Çağlayan HS, Şirin EF, Yıldız Ö. (2008). Beden eğitimi ve spor yüksekokulu öğrencilerinin genel öğrenme stratejilerini kullanma düzeylerinin bazı değişkenlere göre incelenmesi. Türkiye Sosyal Araştırmalar Dergisi, 12(2), 45-62.

23. Çakır Ö, Kan A, Sünbül ö. (2006). Öğretmenlik meslek bilgisi ve tezsiz yüksek lisans programlarının tutum ve öz-yeterlik açısından değerlendirilmesi. Mersin Üniversitesi Eğitim Fakültesi Dergisi, 2(1), 36-47.

24. Çapa Y, Çil N. (2000). Öğretmen adaylarının öğretmenlik mesleğine yönelik tutumlarının farklı değişkenler açısından incelenmesi. Hacettepe Üniversitesi Eğitim Fakültesi Dergisi, 18, 69-73.

25. Çapri B, Çelikkaleli ö. (2008). Öğretmen adaylarının öğretmenliğe ilişkin tutum ve mesleki yeterlik inançlarının cinsiyet, program ve fakültelerine göre incelenmesi. İnönü Üniversitesi Eğitim Fakültesi Dergisi, 9(15), 33-53.

26. Çeliköz N, Çetin F. (2004). Anadolu öğretmen lisesi öğrencilerinin öğretmenlik mesleğine yönelik tutumlarını etkileyen etmenler. Milli Eğitim Dergisi, 162.

27. Çokluk ö, Şekercioğlu G, Büyüköztürk Ş. (2010). Sosyal bilimler için çok değişkenli istatistik: SPSS ve LISREL uygulamaları. Ankara: Pegem Akademi.

28. Dabat Z. (2010). The relation between the (class teacher) students' attitudes towards teaching profession and the level of teaching competency with reference to various variables. Journal of Education and Sociology, 4, 41-46.

29. Darst PW, Pangrazi RP. (2009). Dynamic physical education for secondary school students ( $6^{\text {th }}$ Edition) San Francisco, CA: Pearson Education.

30. Demirtaş H, Cömert M, Özer N. (2011). Öğretmen adaylarının öz-yeterlik inançları ve öğretmenlik mesleğine ilişkin tutumları. Eğitim ve Bilim, 36(159), 96111. 
31. Denizoğlu P. (2008). Fen bilgisi öğretmen adaylarının fen bilgisi öğretimi öz-yeterlik inanç düzeyleri, öğrenme stilleri ve fen bilgisi öğretimine yönelik tutumları arasındaki ilişkinin değerlendirilmesi. Yayımlanmamış Yüksek Lisans Tezi. Çukurova Üniversitesi. Sosyal Bilimler Enstitüsü.

32. Dural S. (2008). Sınıf öğretmeni adaylarının öğrenme ve ders çalışma stratejileri ile başarıları arasındaki ilişki. Yayımlanmamış Yüksek Lisans Tezi. Adnan Menderes Üniversitesi. Sosyal Bilimler Enstitüsü.

33. Durmuşoğlu MC, Yanık C, Akkoyunlu B. (2009). Türk ve Azeri öğretmen adaylarının öğretmenlik mesleğine yönelik tutumları. Hacettepe Üniversitesi Eğitim Fakültesi Dergisi, 36, 76-86.

34. Efe N, Özturan Sağırı M, Ünlü I, Kaşkaya A. (2009). Öğrenme stratejilerinin çeşitli değişkenlere göre incelenmesi. Erzincan Eğitim Fakültesi Dergisi, 11(2), 227-238.

35. Eggen P, Kauchak D. (1997). Educational psychology ( $3^{\text {rd }}$ Edition). New Jersey: Printice Hall, Inc.

36. Er KO, Gürgan U. (2011). Öğretmen adaylarının özyeterlilik algıları ve kopya çekmeye ilişkin tutumları arasındaki ilişki. Balıkesir Üniversitesi Sosyal Bilimler Enstitüsü Dergisi, 14(26), 1-18.

37. Erkuş A, Sanlı N, Bağlı MT, Güven K. (2000), Öğretmenliğe ilişkin tutum ölçeği geliştirilmesi. Eğitim ve Bilim Dergisi, 25(116), 27-33.

38. Fazeli SH. (2012). Use of the metacognitive English language learning strategies based on personality traits. Theory and Practice in Language Studies, 2(3), 531-539.

39. Fırat Durdukoca Ş. (2010). Sınıf öğretmeni adaylarının akademik öz-yeterlik algılarının çeşitli değişkenler açısından incelenmesi. Abant Izzet Baysal Üniversitesi Dergisi, 10(1), 69-77.

40. Girgin RG, Özyılmaz Akamca G, Ellez AM, Oğuz E. (2010). Okul öncesi öğretmen adaylarının öğretmenlik mesleğine yönelik tutumları, mesleki benlik saygıları ve mesleki yeterlik inançları. Buca Eğitim Fakültesi Dergisi, 28, 1-15.

41. Gökçe F, Sezer Gö. (2012). Öğretmen adaylarının öğretmenlik mesleğine yönelik tutumları. Uludağ Üniversitesi Örneği. Eğitim Fakültesi Dergisi, 25(1), 1-23.

42. İflazoğlu Saban A, Tümkaya S. (2008). Öğretmen adaylarının öğrenme stratejileri ile sosyo-demografik özellikler ve akademik başarıları arasındaki ilişkinin incelenmesi. Ege Eğitim Dergisi, 9(1), 1-22.

43. Jaiswal PN. (2013). A study of relationship among teaching efficiency, attitude towards teachıng profession and acedemic achievement of B.Ed. students. Indian Streams Research Journal, 3(3), 1-3.

44. Jerusalem M, Schwarzer R. (1981). Fragebogen zur Erfasung von "Selbstwirksamkeit. Skalen zur Befindlichkeit und Persoenlichkeit. (R Schwarzer, Der.). Forschungsbericht No. 5. Berlin: Freie Universitaet, Institut fuer Psychologie.
45. Kağıtçıbaşı Ç. (1988). Insan ve insanlar: sosyal psikolojiye giriş. İstanbul: Evrim Basım Yayım Dağıtım.

46. Karakaya i. (2012). Bilimsel araştırma yöntemleri (A Tanrı̈ğen, Ed.) Bilimsel araştırma yöntemleri. s.57-87. Ankara: Anı Yayıncılık.

47. Karasar N. (2012). Bilimsel araştırma yöntemi. Ankara: Nobel Akademik Yayıncılık.

48. Kartal T, Kayacan K, Selvi M. (2013). Examining the awareness levels of scientific attitudes and metacognitive learning strategies of preservice teachers from the point of multiple variables. The Journal of Academic Social Science Studies, 6(1), 913939.

49. Kaya K. (2004). Beden eğitimi ve spor yüksekokulu öğrencilerinin öğretmenlik mesleğine yönelik tutumları. Yayımlanmamış Yüksek Lisans Tezi. Gazi Üniversitesi. Eğitim Bilimleri Enstitüsü.

50. Kline RB. (2005). Principles and practice of structural equation modeling: Methodology in the social sciences. New York, NY: Guilford Press.

51. Korkmaz Ö, Usta E. (2010). Öğretmen adaylarının öğretmenlik mesleğine karşı tutumları ile algıladıkları etkileşim-izlenme kaygıları ve problem çözme becerileri arasındaki ilişki. Türkiye Sosyal Araştırmalar Dergisi, 3, $1-22$.

52. Kuzu A. (2013). Bilimsel araştırma yöntemleri. Eskişehir: Anadolu Üniversitesi Yayını.

53. Küçük Kılıç S, Öncü E. (2014). Beden eğitimi ve spor yüksekokulu öğrencilerinin bilişötesi öğrenme stratejileri ve akademik öz-yeterlikleri. Spor ve Performans Araştırmaları Dergisi. 5(2), 13-22.

54. Küçükahmet L. (2008). Öğretimi planlama ve değerlendirme. Ankara: Nobel Yayın Dağıtım.

55. Leutwyler B. (2009). Metacognitive learning strategies: Differential development patterns in high school. Metacognition Learning, 4, 111-123.

56. Liem AD, Lau S, Nie Y. (2008). The role of self-efficacy, task value, and achievement goals in predicting learning strategies, task disengagement, peer relationship, and achievement outcome. Contemporary Educational Psychology. 33( 4), 486-512.

57. McIntire SA, Miller LA. (2000). Foundations of psychological testing. Fairfield, PA: McGraw-Hill Companies.

58. Murat M, Ünişen A, Kanadlı S. (2010). Eğitim fakültesine yeni başlayan öğrencilerin öğretmenlik mesleğini algılayışları ve öğretmenlik mesleğine ilişkin tutumları. Elektronik Sosyal Bilimler Dergisi, 9(33), 226244.

59. Nachmias CF, Nachmias D. (1996). Research methods in the social sciences. ( $5^{\text {th }}$ Edition). New York: St. Martin's Press.

60. Namlu AG. (2004). Bilişötesi öğrenme stratejileri ölçme aracının geliştirilmesi: Geçerlilik ve güvenirlik çalışması. Sosyal Bilimler Dergisi, 2, 123-136.

61. Oğuz A. (2012). Academic self-efficacy beliefs of prospective primary school teacher. Anadolu Journal of Educational Sciences, 2(2), 15-28. 
62. Okçu V, Kahyaoğlu M. (2007). İlköğretim öğretmenlerinin bilişötesi öğrenme stratejilerin belirlenmesi. Süleyman Demirel Üniversitesi Sosyal Bilimler Enstitüsü Dergisi, 2(6), 129-146.

63. Özder H, Konedralı G, Zeki CP. (2010). Öğretmen adaylarının öğretmenlik mesleğine yönelik tutumlarının çeşitli değişkenler açısından incelenmesi. Kuram ve Uygulamada Eğitim Yönetimi, 16(2), 253-275.

64. Özer B. (2002). İlköğretim ve ortaöğretim okullarının eğitim programlarında öğrenme stratejileri. Eğitim Bilimleri ve Uygulama, 1(1), 17-32.

65. Özsüer S, İnal G, Uyanık Ö, Ergün M. (2011). Afyon Kocatepe Üniversitesinde öğrenim gören öğrencilerin akademik öz-yeterlik inanç düzeylerinin incelenmesi. Sosyal Bilimler Dergisi, 13(2), 113-125.

66. Papanastasiou C. (2002). School, teaching and family influence on student attitudes toward science: based on TIMSS data for Cyprus. Studies in Educational Evaluation, 28, 71-86.

67. Pehlivan Z. (2010). Beden eğitimi öğretmen adaylarının fiziksel benlik algıları ve öğretmenlik mesleğine yönelik tutumlarının analizi. Eğitim ve Bilim, 35(136), 126-141.

68. Sağlam M. (1999). Uzaktan eğitim yoluyla öğrenim gören sınıf öğretmenlerinin etkili ders çalışma ve öğrenme stratejilerini uygulama düzeyleri. Anadolu Üniversitesi Eğitim Fakültesi Dergisi, 9(1-2), 17-35.

69. Sala MP, Redford P. (2010). The interplay between motivation, self-efficacy, and approaches to studying. British Journal of Educational Psychology, 80, 283-305.

70. Sandıkçı M, Öncü E. (2013). Beden eğitimi ile diğer alanlardaki öğretmen adaylarının öğretmenlik mesleğine ilişkin yeterlik algıları ve tutumlarının belirlenmesi ve karşılaştırılması. Pamukkale Spor Bilimleri Dergisi, 4(1), 135-151.

71. Saracaloğlu AS. (1992). Beden eğitimi öğretmeni adaylarının mesleğe yönelik tutumları. Spor Bilimleri Dergisi. 3(1), 10-26.

72. Senemoğlu N. (2001). Öğrenci görüşlerine göre öğretmen yeterlilikleri, eğitimde yansımalar: VI. Ankara: Öğretmen Hüseyin Hüsnü TEKIŞIK Eğitim Araştırma Geliştirme Vakfı Yayınları.

73. Sharp C, Pocklington K, Weindling D. (2002). Study support and the development of self-regulated learner. Educational Research, 44, 29-41.

74. Şara P. (2012). Sınıf öğretmeni adaylarının öğrenme ve ders çalışma stratejileri, problem çözme becerileri ve denetim odağı düzeylerinin çeşitli değişkenler açısından incelenmesi. Yayımlanmamış Doktora Tezi. Dokuz Eylül Üniversitesi. Eğitim Bilimleri Enstitüsü.

75. Şen B. (2006). Sınıf öğretmeni adaylarının öğretmenlik tutumları ile öğrenme ve ders çalışma stratejileri arasındaki ilişki. Yayımlanmamış Yüksek Lisans Tezi. Marmara Üniversitesi. Eğitim Bilimleri Enstitüsü.

76. Tabancalı E, Çelik K. (2013). The relationship between academic self-efficacy and self-efficacy levels of teacher candidates. International Journal of Human Sciences. 10(1), 1167-1184.
77. Tavşancıl E. (2006). Tutumların ölçülmesi ve SPSS ile veri analizi. Ankara: Nobel Yayın Dağıtım.

78. Toprak N, Saraç L. (2014). Beden eğitimi ve spor yüksekokulu özel yetenek sınavına başvuran kadın ve erkek adayların öğretmenlik mesleğine karşı tutumlarının incelenmesi. Pamukkale Spor Bilimleri Dergisi, 5(2), 35-47.

79. Uyar M. (2008). Eğitim fakültesi öğrencilerinin ders çalışmada öğrenme stratejileri kullanım sıklığının ve akademik başarılarının karşılaştırılmalı olarak incelenmesi. Yayımlanmamış Yüksek Lisans Tezi. Süleyman Demirel Üniversitesi. Sosyal Bilimler Enstitüsü.

80. Vural L. (2011). Öğretmen adaylarının çalışmalarında yaşadıkları öğrenme sorunları ve kullandıkları öğrenme stratejileri. Dicle Üniversitesi Ziya Gökalp Eğitim Fakültesi Dergisi, 16, 46-65.

81. Weinstein CE, Mayer RE. (1983). The teaching of learning strategies. Innovation Abstracts, 5(32).

82. Yalız D. (2010a). Anadolu Üniversitesi Beden Eğitimi ve Spor Yüksekokulu öğrencilerinin öğrenme stratejileri. Celal Bayar Üniversitesi Beden Eğitimi ve Spor Bilimleri Dergisi, 5(3), 77-86.

83. Yalız D. (2010b). Anadolu Üniversitesi Beden Eğitimi ve Spor Öğretmenliği Bölümü öğrencilerinin öğretmenlik mesleğine yönelik tutumlarının karşılaştırılması. Celal Bayar Üniversitesi Beden Eğitimi ve Spor Bilimleri Dergisi, 5(1), 7-14.

84. Yılmaz M, Gürçay D, Ekici G. (2007). Akademik özyeterlik ölçeğinin Türkçe'ye uyarlanması. Hacettepe Üniversitesi Eğitim Fakültesi Dergisi, 33, 253-259.

85. Zimmerman BJ. (2000). Self-efficacy: An essential motive to learn. Contemporary Educational Psychology, 25, 82-91. 